УДК 577.27:614.449:547.271(047.37)

Бачинський P.O: http://orcid.org/0000-0003-2156-1651

Бачинська Я.О: http://orcid.org/0000-0001-6783-1704

\title{
ДОСЛІДЖЕННЯ СТАНУ ІМУННОЇ СИСТЕМИ ЩУРІВ ПРИ ДІЇ НІТРОБЕНЗОЛУ ТА МЕТИЛТРЕТБУТИЛОВОГО ЕФІРУ В УМОВАХ ХОЛОДОВОГО СТРЕСУ ТА В УМОВАХ ТЕМПЕРАТУРНОГО ОПТИМУМУ
}

\author{
(C) Бачинський P.O. ${ }^{1}$, Бачинська Я.О. ${ }^{2}$ \\ ${ }^{1}$ Харківський національний медичний університет \\ ruslanbach1974@gmail.com \\ ${ }^{2}$ Харківський національний педагогічний університет імені Г. С. Сковороди \\ Bachinska2301@gmail.com
}

https://doi.org/10.34142/ 2708-583X.2019.21.09

\begin{abstract}
У статті наведені результати експериментальних досліджень з вивчення особливостей токсичної дії метилтретбутилового ефіру [МТБЕ] та нітробензолу [НБ] за критеріями змін показників стану імунної системи лабораторних тварин в умовах холодового стресу та в умовах температурного оптимуму.

Дослідження проводили в умовах підгострого експерименту (1 міс. затравочного періоду) на лабораторних тваринах (статевозрілих щурах-самиях лінї WAG). Здійснювали 30-ти кратне введення НБ або МТБЕ в шлунок у дозі 1/10 ЛД 50 (70 мг/кг для НБ, 500 мг/кг для МТБЕ) та утриманням тварин в двох різних температурних режимах по 4 години в день 5 разів на тиждень.
\end{abstract}

Тварини були розділені на 4 групи по 6 тварин у кожній. Тварини 1-ї групи піддавалися дії НБ або МТБЕ при температурі повітря $25 \pm 2{ }^{\circ} \mathrm{C}$ (нормальна температура навколишнього середовища). Тварини 2-ї групи служили контролем по відношенню до тварин 1-ї групи. Тварини 3-ї групи піддавалися дї НБ або МТБЕ у сполученні зі зниженою температурою повітря $4 \pm 2^{\circ} \mathrm{C}$. Тварини 4-ї групи піддавалися ізольованій дії тільки зниженої температури $4 \pm 2^{\circ} \mathrm{C}$, тобто були контролем по відношенню до тварин 3-ї групи.

Аналіз результатів експериментальних даних особливостей імунотоксичної дї̈ НБ та МТБЕ в умовах холодового стресу свідчть про напругу імунної системи лабораторних тварин, яка виражається прогресуючою лімфопенією та зниженням фагоцитарної активності нейтрофілів щзодо поглинання ксенобіотиків, особливо наприкіниі періоду введення (після 30 введень).

Імунотоксична дія НБ та МТБЕ в умовах температурного оптимуму свідчить про тимчасову напругу імунної системи, а саме - лейкоцитоз та лейкопенія на етапі лише після 5 та 15 затравок. Наприкінці затравочного періоду порушень показників стану імунної системи при дї НБ та МТБЕ в умовах температурного оптимуму не відмічалося, що може свідчити про позитивну адаптоспроможність організму лабораторних тварин на дію хімічних чинників (НБ та МТБЕ) за таких температурних умов.

Таким чином, сполучена дія на організм НБ та МТБЕ на рівні їх ефективних концентрачій та зниженої температури обумовлює несприятливий вплив на адаптоспроможність організму. Отже, дані хімічні сполуки на стадії фізіологічної адаптації, тобто до формування патологічного процесу, ускладнюють формування специфічних і неспециифічних реакцій, відповідальних за адаптацію організму до дії іншого чинника виробничого або оточуючого середовища - зниженої температури повітря. Останній, у свою чергу, створює додаткове навантаження на біохімічні системи детоксикаціі, призводить до їх розбалансованості та зміни швидкості біотрансформації хімічного агента і швидкості розвитку токсичного процесу.

Ключові слова: метилтретбутиловий ефір, нітробензол, холодовий стрес, сполучена дія, імунотоксичність, адаптоспроможність.

Умови навколишнього середовища у значній мірі визначають рівень захисних сил організму людини. Це відноситься до широкого спектру факторів навколишнього середовища, як природного, так i штучного походження.

Щорічно у навколишнє середовище потрапляє все більше нових хімічних речовин. Це призводить до 
безперервної зміни хімічного складу середовища проживання людини. Крім того, на людину впливають і інші шкідливі чинники довкілля, зокрема фізичної природи. Найбільш вагомим несприятливим впливом на здоров'я людини можна вважати дію хімічних чинників саме у сполученні зі зниженою температурою повітря $[1,12]$.

Сполучена дія на організм ксенобіотиків та фізичних факторів навколишнього середовища у більшості випадків супроводжується проявом синергетичних ефектів. Це обумовлено перш за все тим, що взаємозалежний ефект хімічних i фізичних факторів середовища проявляється у тих випадках, коли при певній інтенсивності впливу одного 3 них знижується загальна реактивність організму і підвищується чутливість його до дії іншого чинника.

Вплив температурного фактору обумовлений зміною швидкості протікання токсичного процесу та функціонального стану організму (підвищенням чутливості організму до токсичної дії ксенобіотиків, порушенням механізму терморегуляції організму і водносольового обміну, кровообігу, дихання та інших біохімічних про-цесів). При цьому, 3 одного боку, відбувається вплив ксенобіотика на змінений організм, 3 іншого - взаємодія організму та ксенобіотика знижує стійкість організму до дії зниженої температури. Внаслідок цього одночасний вплив на організм шкідливих речовин i зниженої температури навколишнього середовища призводить до непропорційного підсумо- вування їхніх біологічних ефектів, викликаючи так званий «синдром взаємного обтяжен-ня» [2].

Метилтретбутиловий

eфip (МТБЕ) - синтетична хімічна речовина, яка широко використовується у багатьох галузях промисловості. Найбільш широко - як антидетонаційна добавка до бензину. 3 додаванням до бензинових фракцій МТБЕ не лише усувається небезпека забруднення свинцем об'єктів довкілля, а й суттєво підвищується детонаційна стійкість пального, особливо прямогонного бензину та бензину каталітичного риформінгу звичайного режиму [4]. Крім того, МТБЕ підвищує у сумішевих паливах економічні показники їхньої потужності та значно знижує вміст токсичних речовин у відпрацьованих газах: на $15-30 \%$ оксиду вуглецю, на 7 - 8\% - вуглеводнів [11, 14].

МТБЕ не повністю згоряе у двигунах автомобілів і частина його потрапляє у повітря у незміненому стані. Також, МТБЕ може потрапляти у грунтові води за рахунок протікання підземних резервуарів пального та трубопроводів. Внаслідок цього забрудненню можуть піддаватись як атмосферне повітря, так i вода водних об'єктів, що використовуються для водопостачання та господарсько-побутових потреб населення $[8,13,15]$. Таким чином, дії цієї речовини зазнає широке коло працівників та населення загалом.

Більше 97\% світового виробництва нітробензолу [НБ] використовується як сировина для аніліну. Напівпродукти на основі аніліну служать сировиною для 
виробництва практично всіх (за невеликим винятком) класів барвників, анілін широко використовується для виробництва поліуретану, а також для виробництва N-метиланіліну - високооктанової присадки для автомобільних бензинів.

3 НБ також отримують такі хімічні сполуки як, бензидин, хінолін, азобензол. В промисловості НБ широко використовується як розчинник для целюлозних етерів $\mathrm{i}$ ацетатів, а також для очистки змащувальних мастил. Крім того, НБ застосовується при виробництві фармпрепаратів, мила, товарів побутової хімї, сільськогосподарських отрутохімікатів, в парфумерній промисловості, як вихідний продукт для одержання вибухових речовин, реагент в аналітичній практиці, компонент полірувальних складів для металів [7].

Процеси синтезу речовин на основі НБ, рівно як і синтез самого нітробензолу, пов'язані з можливим виділенням останнього у повітря виробничих приміщень, а також забрудненням обладнання, одягу i шкірних покривів працюючих, тобто негативна дія НБ на організм пов'язана в основному 3 професійною діяльністю. Проте відомо, що при синтезі НБ втрати зі стічними водами складають близько 2\% від загального виробництва НБ. Деяка частина його потрапляє у атмосферне повітря, грунт, що може нести потенційну небезпеку дії НБ на населення, особливо на ту його частину, що проживає поблизу джерел забруднення [9].

Виходячи 3 актуальності теми, метою проведення експериментальних досліджень було вивчення особливостей токсичної дії МТБЕ та НБ за критеріями змін показників стану імунної системи лабораторних тварин в умовах холодового стресу та в умовах темпе-ратурного оптимуму.

\section{МАТЕРІАЛИ ТА МЕТОДИ ДОСЛЦДЖЕНЬ}

Дослідження проводили в умовах підгострого експерименту (1 міс. затравочного періоду) на лабораторних тваринах (статевозрілих щурах-самцях лінії WAG). Здійснювали 30-ти кратне внутрішнє введення НБ або МТБЕ в шлунок у дозі 1/10 ЛД мг/кг для МТБЕ) та утриманням тварин у двох різних температурних режимах по 4 години на день, 5 разів на тиждень. При цьому речовини вводили у шлунок за допомогою спеціального зонду - НБ у вигляді $1 \%$ розчину на соняшниковій олії (тваринам контрольної групи у еквівалентній дозі вводили соняшникову олію), МТБЕ у вигляді водного розчину (тваринам контрольної групи у еквівалентній дозі вводили дистильовану воду).

Тварини були розділені на 4 групи по 6 тварин у кожній. Тварини 1-ї групи піддавалися дії НБ або МТБЕ при температурі повітря $25 \pm 2^{0} \mathrm{C}$ (нормальна температура навколишнього середовища). Тварини 2-ї групи - контрольна група, при температурі повітря $25 \pm 2{ }^{0} \mathrm{C}$. Тварини 3-ї групи піддавалися дії НБ або МТБЕ у сполученні зі зниженою температурою повітря $4 \pm 2{ }^{\circ} \mathrm{C}$. Тварини 4-ї групи піддавалися ізольованій дії тільки зниженої 
температури $4 \pm 2^{0} \mathrm{C}$, тобто були контролем по відношенню до тварин 3-ї групи.

Роботу виконано на лабораторних тваринах 3 експериментальнобіологічної клініки ХНМУ 3 урахуванням норм збе-рігання, догляду і годування, затве-рджених згідно принципів «Європейської конвенції про захист хребетних тварин, які використовуються в експериментальних та інших наукових цілях (Директива 2010/63/EU Європейського парламенту від 22 вересня 2010 року [10] та ухвали Першого національного конгресу 3 біоетики (Київ, 2007) [5]. Досліди проводилися в першій половині дня 3 урахуванням циркадних ритмів [3]. Холодовий стрес моделювали в умовах 200-літрової затравочної камери загального призначення, додатково обладнаної комірками, для ізольованого вільного розміщення тварин, а також термоелектричним охолоджуючим пристроєм типу «повітря-повітря», що забезпечує охолоджування повітряного середовища в діапазоні температур $4 \pm 2^{\circ} \mathrm{C}$ [пат. № 39237].

Досліджувалися показники стану імунної системи щурів, що знаходилися в умовах сполученої дії МТБЕ та холодового фактору в дина- міці після 5, 15 та 30 введень. Контрольні тварини знаходилися тільки в умовах дії зниженої температури (холодовий контроль). Для інтегральної оцінки імунного статусу визначали загальну кількість лейкоцитів, процентний вміст лімфоцитів та нейтрофілів, відсоток нейтро-філів, що фагоцитували (фагоцитарна активність нейтрофілів кро-ві), та рівень циркулюючих імунних комплексів (ЦІК) [4]. Кількість лейкоцитів, лімфоцитів та нейтрофілів визначали уніфікованим методом підрахунку в камері Горяєва. Фагоцитарну активність нейтрофілів визначали за показником фаго-цитарного індексу (ФІ), тобто відсо-тку клітин, що вступили в фагоцитоз відносно їх загальної кількості. Для оцінки рівня ЦІК використовували метод преципітації з 3,5\% розчином поліетиленгліколя ПЕГ-тест ОП280. Отримані дані опрацьовано загально-прийнятими методами статистики (середня, похибка середньої, крите-рій вірогідності Фішера-Стьюдента).

\section{РЕЗУЛЬТАТИ ТА ÏХ ОБГОВОРЕННЯ}

Дані імунного статусу щурів, що знаходилися під дією МТБЕ або НБ в умовах температурного комфорту наведені в табл. 1.

Таблиия 1

Результати досліджень імунологічного стану щурів при дії НБ та МТБЕ в умовах температурного оптимуму $\left(\mathrm{t}=25 \pm 2^{0} \mathrm{C}\right)$

\begin{tabular}{|l|c|c|c|}
\hline \multicolumn{1}{|c|}{$\begin{array}{c}\text { Показники, } \\
\mathrm{N}=6\end{array}$} & $\begin{array}{c}\text { Контроль } \\
\left(\mathrm{t}=+25 \pm 2^{0} \mathrm{C}\right)\end{array}$ & $\begin{array}{c}\text { НБ } \\
\left(\mathrm{t}=+25 \pm 2^{0} \mathrm{C}\right)\end{array}$ & $\begin{array}{c}\text { МТБЕ } \\
\left(\mathrm{t}=+25 \pm 2^{0} \mathrm{C}\right)\end{array}$ \\
\hline \multicolumn{4}{|c|}{5 затравок } \\
\hline Лейкоцити & $12.40 \pm 0.40$ & $16.40 \pm 1.19^{*}$ & $15.28 \pm 2.75^{*}$ \\
\hline Нейтрофіли & $36.83 \pm 3.32$ & $29.67 \pm 1.17$ & $35.12 \pm 3.83$ \\
\hline Лімфоцити & $58.83 \pm 0.70$ & $42.33 \pm 5.33^{*}$ & $44.80 \pm 1.57^{*}$ \\
\hline ЦІК & $8.50 \pm 0.58$ & $7.40 \pm 0.30$ & $6.60 \pm 0.83$ \\
\hline Фагоцитоз & $67.15 \pm 1.52$ & $66.21 \pm 1.77$ & $65.83 \pm 2.35$ \\
\hline
\end{tabular}


Бачинський Р.О., Бачинська Я.О., 2019

\begin{tabular}{|l|r|r|r|}
\hline \multicolumn{5}{|c|}{15 затравок } \\
\hline Лейкоцити & $12.75 \pm 0.76$ & $16.42 \pm 0.91^{*}$ & $13.15 \pm 1.77$ \\
\hline Нейтрофіли & $31.50 \pm 2.08$ & $26.43 \pm 3.03$ & $29.77 \pm 5.82$ \\
\hline Лімфоцити & $69.17 \pm 4.61$ & $44.17 \pm 3.75^{*}$ & $57.51 \pm 0.76^{*}$ \\
\hline ЦК & $21.67 \pm 5.87$ & $19.52 \pm 1.89$ & $20.75 \pm 1.20$ \\
\hline Фагоцито3 & $72.81 \pm 1.24$ & $69.27 \pm 2.52$ & $66.42 \pm 3.50$ \\
\hline \multicolumn{3}{|c|}{30 затравок } \\
\hline Лейкоцити & $13.08 \pm 0.35$ & $13.43 \pm 0.35$ & $12.48 \pm 0.44$ \\
\hline Нейтрофіли & $38.67 \pm 2.97$ & $33.00 \pm 1.88$ & $32.43 \pm 1.94$ \\
\hline Лімфоцити & $67.80 \pm 2.60$ & $63.16 \pm 3.41$ & $64.20 \pm 1.69$ \\
\hline ЦІК & $13.58 \pm 2.64$ & $11.08 \pm 2.93$ & $10.83 \pm 1.92$ \\
\hline Фагоцитоз & $75.00 \pm 2.74$ & $69.61 \pm 1.29$ & $69.17 \pm 2.92$ \\
\hline
\end{tabular}

Примітка: * - різниця 3 контролем вірогідна $(\mathrm{P}<0,05)$

Токсична дія НБ та МТБЕ в умовах температурного оптимуму на порушення показників стану імунної системи щурів має схожість (див. табл. 1). А саме, на етапі після 5 затравок, призводила до статистично значимого підвищення кількості лейкоцитів та зменшення кількості лімфоцитів, у порівнянні з контрольною групою. На етапі після 15 затравок токсична дія НБ призводила до лейкоцитозу, також на цьому ж етапі спостерігалася лімфопенія, як при дії НБ, так і МТБЕ. Наприкінці затравочного періоду (після 30 затравок) дія НБ та МТБЕ в умовах температурного оптимуму не призводила до зрушення показників стану імунної системи, що вивчалися в порівнянні 3 контрольною групою лабораторних тварин.

Таким чином, отримані експериментальні дані свідчать про те, що в умовах температурного оптимуму на початковому етапі експерименту (після 5 та 15 затравок) імунотоксична дія НБ та МТБЕ призводила до пригнічення лімфопоезу або прискорення загибелі лімфоцитів, а також до появи відповідної захисної реакції організму на дію екзогенного агента (НБ або МТБЕ) - лейкоцитозу. Наприкінці затравочного періоду (після 30 затравок) дія НБ та МТБЕ не призводила до зрушення показників стану імунної системи щурів, що може свідчити про позитивну адаптоспроможрість організму лабораторних тварин на дію НБ або МТБЕ в умовах температурного оптимуму.

Результати експериментальних досліджень зрушення показників стану імунної системи щурів при дії НБ та МТБЕ в умовах холодового стресу приведені в табл. 2.

\section{Таблиия 2}

Результати досліджень імунологічного стану щурів при дії НБ та МТБЕ в умовах холодового стресу $\left(\mathrm{t}=4 \pm 2^{0} \mathrm{C}\right)$

\begin{tabular}{|l|c|c|c|}
\hline \multicolumn{1}{|c|}{$\begin{array}{l}\text { Показники, } \\
\mathrm{N}=6\end{array}$} & $\begin{array}{c}\text { Контроль } \\
\left(\mathrm{t}=+4 \pm 2^{0} \mathrm{C}\right)\end{array}$ & $\begin{array}{c}\text { НБ } \\
\left(\mathrm{t}=+4 \pm 2^{0} \mathrm{C}\right)\end{array}$ & $\begin{array}{c}\text { МТБЕ } \\
\left(\mathrm{t}=+4 \pm 2^{0} \mathrm{C}\right)\end{array}$ \\
\hline \multicolumn{4}{|c|}{5 затравок } \\
\hline Лейкоцити & $10.55 \pm 0.90$ & $21.83 \pm 6.17$ & $8.10 \pm 0.81^{* *}$ \\
\hline Нейтрофіли & $35.33 \pm 4.29$ & $22.83 \pm 5.94$ & $34.50 \pm 3.38$ \\
\hline Лімфоцити & $64.17 \pm 4.09$ & $77.17 \pm 5.94$ & $65.50 \pm 3.38$ \\
\hline ЦІК & $7.38 \pm 1.34$ & $4.78 \pm 1.34$ & $6.40 \pm 1.36$ \\
\hline Фагоцитоз & $67.17 \pm 1.74$ & $59.17 \pm 4.48$ & $43.50 \pm 2.32^{*}$ \\
\hline
\end{tabular}


БІОЛОГІЯ ТА ВАЛЕОЛОГІЯ, ВИП. 21

\begin{tabular}{|l|c|c|c|}
\hline \multicolumn{4}{|c|}{15 затравок } \\
\hline Лейкоцити & $11.20 \pm 1.33$ & $8.06 \pm 1.22$ & $9.14 \pm 1.13$ \\
\hline Нейтрофіли & $26.60 \pm 3.36$ & $23.60 \pm 3.01$ & $20.40 \pm 2.50$ \\
\hline Лімфоцити & $73.40 \pm 3.36$ & $62.40 \pm 5.01$ & $79.60 \pm 2.50$ \\
\hline ЦІК & $17.20 \pm 2.29$ & $18.48 \pm 1.48$ & $17.90 \pm 0.89$ \\
\hline Фагоцито3 & $72.60 \pm 1.72$ & $65.80 \pm 0.97^{*}$ & $64.40 \pm 2.09^{*}$ \\
\hline \multicolumn{4}{|c|}{30 затравок } \\
\hline Лейкоцити & $13.65 \pm 2.21$ & $11.27 \pm 4.24$ & $6.50 \pm 0.56^{*}$ \\
\hline Нейтрофіли & $40.17 \pm 4.29$ & $31.17 \pm 2.37^{*}$ & $20.67 \pm 3.05^{*}$ \\
\hline Лімфоцити & $70.77 \pm 0.75$ & $64.82 \pm 1.36^{*}$ & $61.63 \pm 2.29^{*}$ \\
\hline ЦІК & $11.22 \pm 3.60$ & $12.83 \pm 1.62$ & $10.33 \pm 1.82$ \\
\hline Фагоцитоз & $69.67 \pm 1.28$ & $49.67 \pm 2.50^{*}$ & $53.00 \pm 1.18^{*}$ \\
\hline
\end{tabular}

Примітка: * - різниця 3 контролем вірогідна $(\mathrm{P}<0,05)$; ** - різниця 3 контролем близька до вірогідної $(0,05<\mathrm{P}<0,1)$

Результати імунотоксичної дії НБ та МТБЕ в умовах холодового стресу носять дещо інший характер ніж результати попереднього дослідження, але теж мають загальні риси, особливо наприкінці затравочного періоду (див. табл. 2).

Так, дія МТБЕ в умовах холодового стресу призводила до статистично значимого зменшення кількості лейкоцитів на етапах після 5 та 30 затравок, чого не спостерігалося при дії НБ на цих же етапах. Також наприкінці затравочного періоду, як при дії НБ так і МТБЕ зареєстровано статистично значиме зниження кількості нейтрофілів та лімфоцитів. ФI був статистично значимо пониженим при дії обох хімічних агентів практично на усіх етапах експерименту.

Таким чином, результати вивчення імунного статусу щурів при введенні НБ або МТБЕ в умовах холодового стресу виявили напругу імунної системи лабораторних тварин, про що свідчить лімфопенія, зниження кількості нейтрофілів та ФІ. Це свідчить про зниження фагоцитарної активності нейтрофілів щодо поглинання чужорідних агентів, у нашому випадку - НБ або
МТБЕ. Прояв даних зрушень особливо помітним становиться наприкінці експерименту (після 30 затравок).

Слід зазначити, що для визначення можливого впливу холодового чинника на зрушення показників стану імунної системи щурів, що досліджувалися, було проведено порівняльну характеристику результатів між двома контрольними групами: «контроль - знижена температура» $\left(\mathrm{t}=4 \pm 2^{0} \mathrm{C}\right)$ і «контроль термонейтральна зона» $\left(\mathrm{t}=25 \pm 2^{0} \mathrm{C}\right)$. При порівнянні результатів між двома контрольними групами статистично значимої різниці упродовж всього експерименту не виявлено.

\section{ВИСНОВКИ}

1. Аналіз результатів експериментальних даних особливостей імунотоксичної дії НБ та МТБЕ в умовах холодового стресу свідчить про напругу імунної системи лабораторних тварин, яка виявляється прогресуючою лімфопенією та зниженням фагоцитарної активності нейтрофілів щодо поглинання чужорідних агентів, особливо наприкінці затравочного періоду (після 30 затравок). 
2. Імунотоксична дія НБ та МТБЕ в умовах температурного оптимуму свідчить про тимчасову напругу імунної системи, а саме лейкоцитоз та лейкопенія на етапі лише після 5 та 15 затравок. Наприкінці затравочного періоду зрушень показників стану імунної системи при дії НБ та МТБЕ в умовах температурного оптимуму не відмічалося, що може свідчити про позитивну адаптоспроможність організму лабораторних тварин на дію хімічних чинників (НБ або МТБЕ) за таких температурних умов.

3. Сполучена дія на організм НБ або МТБЕ на рівні їх ефективних концентрацій та зниженої температури обумовлює несприятливий вплив на адаптоспроможність організму. Дані хімічні сполуки на стадії фізіологічної адаптації, тобто до формування патологічного процесу, ускладнюють формування специфічних і неспецифічних реакцій, відповідальних за адаптацію організму до дії іншого чинника виробничого або оточуючого середовища - зниженої температури повітря. Останній, у свою чергу, створює додаткове навантаження на біохімічні системи детоксикації, призводить до їх розбалансованості та зміни швидкості біотрансформації хімічного агента та швидкості розвитку токсичного процесу.

\section{Список використаних джерел}

1. Zavhorodnii, I. V. (2017). Dosvid eksperymentalnoho vyvchennia efektiv spoluchenoi dii khimichnykh ta fizychnykh chynnykiv. Aktualni problemy profilaktychnoi medytsyny, 1(14), 50-60.

2. Zabolotskykh, V.V., Vasylev, A.V., Tereshchenko, Yu.P. (2016). Cynerhetycheskye effekty pry odnovremennom vozdeistvyy fyzycheskykh y khymycheskykh faktorov. Yzvestyia Samarskoho nauchnoho tsentra Rossyiskoi akademyy nauk, 5(2), 290-295.

3. Zapadniuk, Y.P., Zapadniuk, V.Y., Zakharyl, E.A. (1983). Laboratornye zhyvotnye: razvedenye, soderzhanye, yspolzovanye $\mathrm{V}$ эksperymente. K. : Vyshcha shk., 243-297, 342376.

4. Menshykov, V.V., Delektorskaia, L.N., Zolotnytskaia, R.P. y dr. (1987). Laboratornye metody yssledovanyia v klynyke. Spravochnyk. M. : Medytsyna, $368 \mathrm{~s}$.

5. Suchasni problemy bioetyky. (2009). Pid. red. Yu. I. Kundiiev. K. : «Akademperiodyka», 278 s.

6. Iavorovskyi, O. P. (2005). Metyl-tretbutylovyi efir yak hlobalnyi zabrudniuvach dovkillia. Toksykolohichni ta ekolohichni aspekty ryzyku vplyvu v Ukraini. Dovkillia ta zdorovia, 1, 7580.ATSDR. (1990). Toxicological proflle for Nitrobenzene. Agency for Toxic Substances and Disease Registry U.S. Public Health Servise, 109 p.

7. Asher, W.E., Luo, W., Campo, K.W. [et al.] (2007). Application of a source apportionment model in consideration of volatile organic compounds in an urban stream. Environ Toxicol Chem, 26(8), 1606-1613.

8. EPA. (2009). Toxicological Review of Nitrobenzene (CAS No. 98-95-3). U.S. Environmental Protection Agency, Washington, $D C, 250 \mathrm{p}$.

9. European convention for the protection of vertebrate animals used for experimental and other scientific purposes. (2010). Council of European. Strasbourg, 63. $-51 \mathrm{p}$.

10. Johnson, R., Pankow, J.F., Bender, D.A. [et al.]. (2000). MTBE To what extent will past releases contaminate community water supply wells? Environmental Science \& Technology, 34(9), 210-217.

11. Sidorov, A.I. (2018). Joint effect of physical factors of different nature on the human. Perm Journal of Petroleum and Mining Engineering, $17(1), \quad 60-70 . \quad$ DOI: $10.15593 / 2224-$ 9923/2018.1.6

12. Vandecasteele, Jean-Paul. (2008). Petroleum Microbiology. Editions Technip. Paris, $816 \mathrm{p}$

13. Westphal , G.A., Krahl, J., Bruning, T. [et al.]. (2010). Ether oxygenate additives in gasoline reduce toxicity of exhausts: Toxicology. 268(3), 198-203. DOI:10.1016/j.tox.2009.12.016.

14.Zavgorodnij, I., Thielmann, B., Kapustnik, W., Batschinskij, R., Batschinskaja, J., Böckelmann, I. (2019). Toxizität von Methyltert-butylether auf innere Organe von Versuchstieren unter Kältebedingungen. Zentralblatt für Arbeitsmedizin, Arbeitsschutz und Ergonomie, 13(106), 1-11. DOI:10.1007/s40664-019-0337-6 
UDC 577.27:614.449:547.271(047.37)

\title{
THE STUDY OF THE STATE OF THE IMMUNE SYSTEM OF RATS IN THE ACTION OF NITROBENZOL AND METHYLTRETBUTYL ETHER IN CONDITIONS OF COLD STRESS AND UNDER TEMPERATURE OPTIMUM
}

\author{
R.O. Bachinsky, Ya.O. Bachynska
}

The article describes the results of experimental studies aimed at investigating toxic effects of methyl tertbutyl ether [MTBE] and nitrobenzene [NB] according to the criteria of changes in the immune system status of laboratory animals in conditions of cold stress and in conditions of temperature optimum.

The research was carried out in the conditions of a subacute experiment (during one month of experiment) on laboratory animals (adult WAG male rats). The NB or MTBE were injected into the stomach at a dosage 1/10 LD50 (70 mg/kg of NB and $500 \mathrm{mg} / \mathrm{kg}$ MTBE) thirty times, the experimental animals were kept in two different temperature conditions during four hours five times per week.

The animals were divided into 4 groups, six animals in each group. The animals of the first group were subjected to $N B$ or MTBE at an air temperature of $25 \pm 2^{\circ} \mathrm{C}$ (normal ambient temperature). The animals of the second group served as a control group for the first one. The animals of the third group were subjected to $N B$ or MTBE in combination with the lowered air temperature of $4 \pm 2^{\circ} \mathrm{C}$. The animals of the fourth group were only subjected to the effect of the reduced temperature of $4 \pm 20^{\circ} \mathrm{C}$, that is, they were a control group for the ones of the third group.

The analysis of the results of the experimental data about the features of the immunotoxic action of $N B$ and MTBE under conditions of cold stress indicates the tension of the immune system of the laboratory animals, which is manifested by progressive lymphopenia and a decrease in the phagocytic activity of neutrophils in absorption of foreign agents, especially in the end-period.

The immunotoxic effect of $N B$ and MTBE under conditions of temperature optimum indicates a temporary immune system tension, namely leukocytosis and leukopenia at the stage only after 5 and 15 priming. At the end of the priming period, shifts in the immune system's performance under the effect of $N B$ and MTBE under temperature optimum conditions were not observed, which may indicate a positive adaptability of laboratory animals to the action of chemical factors (NB and MTBE) under such temperature conditions.

The combined effect of $N B$ and MTBE on the body at the level of their effective concentrations and low temperature causes a detrimental effect on the adaptability of the body. Thus, these chemical compounds at the stage of physiological adaptation, that is before the formation of the pathological process, complicate the formation of specific and nonspecific reactions responsible for the adaptation of the organism to the effect of another factor in the production or environment - a low air temperature. The latter, in turn, creates an additional load on biochemical detoxification systems, leads to their imbalance and changes in the rate of biotransformation of the chemical agent and the speed of development of the toxic process.

Key words: methyl tertbutyl ether, nitrobenzene, cold stress, combined effect, immunotoxicity, adaptability.

Стаття надійшла 04. 08. 2019 р.

Рекомендована до друку на засіданні редакційної колегї після рецензування 